\author{
Marta Bolińska \\ Uniwersytet Jana Kochanowskiego w Kielcach \\ Katarzyna Komorowska \\ Zespół Oświatowych Placówek Integracyjnych w Micigoździe k. Kielc
}

\title{
ZAUFANIE - BEZPIECZEŃSTWO - ROZWÓJ. Metoda Ruchu Rozwijającego Weroniki Sherborne DLA WSZYSTKICH
}

\begin{abstract}
Confidence - security - development. Veronica Sherborne's Developmental Movement. Movement is a natural means of communication, and people often express themselves through it. The contemporary theory of physical education and the Developmental Movement by Veronica Sherborne both stem from Laban's observations and experiences. The Developmental Movement Method is a nonverbal interpersonal training; it utilizes touch, movement, physical correlation, emotional and social relationships; as it refers to the early childhood experiences of people. Movement makes one realize the importance of balance whence physical contact is a source of sensory impressions. The advocate and promoter of the aforementioned method is prof. Marta Bogdanowicz (born 1943), who educates people and encourages the implementation of polysensory approach in therapeutic work. Marta Bogdanowicz is a paediatric clinical psychologist, former director of the Institute of Psychology at the University of Gdańsk, the founder and a longtime chairman, currently the vice-president, of Polish Dyslexia Association (1990), the vice-president of the European Dyslexia Association and a member of a number of international scientific societies. She is the author of over 300 publications, including 40 books and a number of non-serials: Portraits of not only famous adults with dyslexia, Gdańsk 2008, Good Start Method, Warsaw 2005, Risk of dyslexia, Gdańsk 2005, What to play with children?, Gdańsk 2004, Cuddles, Gdańsk 2003.
\end{abstract}


Zaufanie - bezpieczeństwo - rozwój. Metoda ruchu rozwijającego Weroniki Sherborne dla wszystkich. Ruch stanowi naturalny środek komunikacji, a ludzie często porozumiewają się za jego pośrednictwem. Z obserwacji i doświadczeń Rudolfa Labana wywodzi się współczesna teoria wychowania fizycznego oraz ruch rozwijający Weroniki Sherborne. Metoda Ruchu Rozwijającego zaliczana jest do niewerbalnych treningów interpersonalnych; korzysta z dotyku, ruchu i wzajemnych relacji fizycznych, emocjonalnych, społecznych; odwołuje się do wczesnodziecięcego doświadczenia człowieka. Ruch uświadamia znaczenie narządu równowagi, kontakt fizyczny stanowi źródło wrażeń dotykowych. Jego zwolenniczką i propagatorką jest prof. Marta Bogdanowicz (ur. 1973), która kształci rzesze osób zainteresowanych oraz zachęca do wdrażania metod polisensorycznych w pracy terapeutycznej. Marta Bogdanowicz to psycholog kliniczny dziecięcy, była dyrektor Instytutu Psychologii Uniwersytetu Gdańskiego, założycielka, wieloletnia przewodnicząca, a obecnie wiceprzewodnicząca Polskiego Towarzystwa Dysleksji (1990), wiceprzewodnicząca European Dyslexia Association (Europejskiego Towarzystwa Dysleksji), członek międzynarodowych towarzystw naukowych. Jest autorką ponad 300 publikacji, w tym 40 książek i publikacji zwartych, m.in.: Portrety nie tylko sławnych osób z dysleksją, Gdańsk 2008, Metoda Dobrego Startu, Warszawa 2005, Ryzyko dysleksji, Gdańsk 2005, W co się bawić z dziećmi?, Gdańsk 2004, Przytulanki, Gdańsk 2003.

Keywords security, development, confidence, Veronica Sherborne's Developmental Movement bezpieczeństwo, rozwój, zaufanie, Ruch Rozwijający Weroniki Sherborne

Z obserwacji i doświadczeń Rudolfa Labana wywodzi się współczesna teoria wychowania fizycznego oraz Metoda Ruchu Rozwijającego Weroniki Sherborne. MRRWS zaliczana jest do niewerbalnych treningów interpersonalnych. Korzysta z dotyku, ruchu i relacji fizycznych oraz emocjonalno-społecznych; odwołuje się do wczesnodziecięcego doświadczenia człowieka. Ruch sprzyja doznaniom kinestetycznym, budowaniu samoświadomości i zaufania do innych; eksponuje znaczenie narządu równowagi. Jego zwolenniczką i propagatorką jest Marta Bogdanowicz ${ }^{1}$, która kształci rzesze osób zainteresowanych oraz zachęca do wdrażania metod polisensorycznych w pracy terapeutycznej.

1 Prof. Marta Bogdanowicz (ur. 1943) chętnie dzieli się wiedzą i doświadczeniem podczas wykładów, kursów, szkoleń i warsztatów. Mieszka w Gdańsku, ale odwiedza też Kraków i inne miasta. Jest autorką ponad 300 publikacji, w tym 40 książek i publikacji zwartych, m.in.: Protrety nie tylko sławnych osób $z$ dysleksją, Gdańsk 2008, Metoda Dobrego Startu, Warszawa 2005, Ryzyko dysleksji, Gdańsk 2005, W co się bawić z dziećmi?, Gdańsk 2004, Przytulanki, Gdańsk 2003. Zob. https://pl.wikipedia.org/wiki/Marta_Bogdanowicz (20.12.2017). 


\section{KONTEKST HISTORYCZNY}

Ruch jest nieodłącznym, naturalnym i niezbędnym składnikiem życia człowieka. Już Platon i Arystoteles wskazywali na związek doświadczenia fizycznego z rozwojem intelektualnym. Znaczenie ruchu w rozwoju osobowości dostrzegali i wykorzystywali w praktyce edukacyjnej znani pedagodzy: Rudolf Steiner, Emile Jacques-Dalcroze czy Rudolf von Laban. Temu ostatniemu zawdzięczamy studia nad ruchem ludzkim i jego wpływem na rozwój jednostki. Na naturalne potrzeby i skłonności człowieka wskazał właśnie Rudolf Laban (1879-1958), który uważał, że ruch jest wyrazem potrzeby ludzkiej aktywności. Stałe ograniczanie go prowadzi do wzrastania wewnętrznego napięcia, stresów i zahamowań, a w konsekwencji jest przyczyną utraty wiary we własne możliwości, zamykania się w sobie, unikania kontaktów z otoczeniem. Laban doszedł do wniosku, że idealną bryłą, za pomocą której można zobrazować wszelkie możliwości ruchowe ludzkiego ciała, jest kula. Opisanie ruchu na jej podstawie byłoby jednak dość trudne ze względu na brak jednoznacznie uchwytnych punktów orientacyjnych. Znacznie lepiej służy do tego celu sześcian, za pomocą którego można wyznaczyć trzy podstawowe kierunki, w których porusza się ludzkie ciało: przód- tył, prawo-lewo, góra-dół.

Laban uznał, że skoro ludzie mają umiejętność porozumiewania się za pomocą ciała, to ruch trzeba uznać za naturalny środek komunikacji oraz narzędzie wspomagające rozwój. Według niego do najważniejszych potrzeb człowieka należy zaliczyć potrzeby: odprężenia, ekspresji i tworzenia. Wszystkie je można zaspokoić w twórczym i kreatywnym tańcu. Jako twórca i propagator metody gimnastyki ekspresyjnej (inaczej metody improwizacji ruchowej) i nowoczesnego tańca wychowawczego, Laban przyczynił się również do powstania ergonomii (nauki o psychofizycznych możliwościach ludzkiego ciała w warunkach pracy). Choreograf podjął badania polegające na obserwacji naturalnych możliwości ruchowych człowieka. Ruchy ujął w specjalne skale, co zaowocowało uchwyceniem trójwymiarowości wedle osi: przód-tyl, prawo-lewo, góra-dół. Bardziej złożone ruchy zostały usytuowane w trzech płaszczyznach: drzwiowej, stołowej i poprzecznej. Jego zdaniem połączenie podstawowych elementów ruchu tworzy figurę geometryczną, tj. sześcian ( $w$ takim uproszczonym modelu przestrzennym mieszczą się zasadnicze możliwości ruchowe człowieka). Wnikliwsza analiza ruchów ludzkich umożliwiła dalszą rozbudowę modelu przestrzennego do dwudziestościanu - bryły najbardziej zbliżonej do kuli. Taka perspektywa może najpełniej oddać potencjał ruchowy tancerza.

W latach sześćdziesiątych XX wieku Weronika Sherborne (1922-1990; pedagog, nauczycielka wychowania fizycznego, fizjoterapeutka, uczennica Labana, autorka licznych prac z zakresu wychowania i terapii dzieci z zaburzeniami rozwoju) wypracowała system ćwiczeń w celu wspomagania prawidłowego rozwoju dzieci i korygowania zaburzeń. Ćwiczenia korzystają ze zdobyczy szkoły Rudolfa Labana i doświadczeń własnych terapeutki. Znane są pod nazwą Ruch Rozwijający. Nazwa Ruch Rozwijający wyraża główną ideę metody: posługiwanie się ruchem jako narzędziem wspomagania rozwoju psychoruchowego i terapii tego rozwoju.

Metoda Weroniki Sherborne jest nastawiona na wzmacnianie poprzez ruch i zabawę wzrastania zarówno fizycznego, jak i emocjonalno-społecznego oraz na korygowanie 
już istniejących zaburzeń. Ważnym elementem i etapem jest dostrzeżenie roli tzw. języka ciała. Dotyk, bliskość osób (szczególnie rodziców), świadomość budowy własnego organizmu, utrzymywanie kontaktu wzrokowego i budowanie zaufania we współpracy z innymi sprzyjają powstawaniu i wzmacnianiu poczucia bezpieczeństwa. Proponowane w MRRWS formy przypominają ulubione zabawy najmłodszych, są proste i naturalne (np. turlanie się po podłodze, masaż ciała, huśtanie, zabawy w kręgu, naśladowanie min i gestów). Skłaniają do aktywności ruchowej, nawiązywania relacji z drugim człowiekiem, pokonywania własnych słabości czy ograniczeń, twórczego działania. Umożliwiają relaks, pomagają osiągnąć spokój, odprężenie. Zaletą zajęć MRRWS jest fakt, że do ich przeprowadzenia nie są potrzebne drogie rekwizyty. Wystarczy dużo wolnej przestrzeni, twórcze pomysły, chęć do zabaw i skromne wyposażenie (np. pomoce terapeutyczne - materac, piłka, chusta, koc), przydać się może świeże powietrze. Istotny jest także udział rodziców, którzy pracują razem z dzieckiem. Uważa się nawet, że najwłaściwszym „przyrządem” dydaktycznym dla dziecka jest ciało dorosłego. Ćwiczenia zwykle wykonuje się boso (dopuszcza się ćwiczenia w skarpetkach). Prowadzeniem grupy powinni zajmować się wykwalifikowani terapeuci (najlepiej dwie osoby) ${ }^{2}$.

Metodę można stosować indywidualnie (praca z jednym dzieckiem) lub grupowo. Preferowane są jednak zajęcia zespołowe, ponieważ zapewniają lepszy kontakt (np. dziecko-dorosły). Optymalna liczebność grupy to 6-14 osób. Wiek uczestników zdaje się nieograniczony; w zajęciach mogą brać udział osoby na różnych etapach życia (dzieci i dorośli). Jeśli metoda stosowana jest w placówkach opiekuńczo-wychowawczych, w spotkaniach powinien brać udział cały personel. Zajęcia powinny też odbywać się systematycznie, przynajmniej raz w tygodniu przez ok. godzinę (dla dzieci młodszych można skrócić czas do ok. pół godziny). Ze względu na samopoczucie, możliwości psychofizyczne czy wiek uczestników czas można modelować (skracać lub wydłużać).

\section{Zaeożenia Metody Ruchu Rozwijającego}

Podstawowe założenia metody Weroniki Sherborne czerpią z doświadczeń i propozycji Labana, ponieważ kładą nacisk na rozwijanie komunikacji przez ruch, co prowadzi do świadomości własnego ciała i usprawniania ruchowego, świadomości przestrzeni i działania w niej. Aktywności wywodzą się z naturalnych potrzeb dziecka, które są zaspokajane w kontakcie z dorosłymi w trakcie tak zwanego baraszkowania. Udział w ćwiczeniach metodą Weroniki Sherborne ma na celu stworzenie dziecku okazji do poznania własnego ciała, usprawnienia motoryki, poczucia swojej siły, sprawności i w związku z tym możliwości ruchowych. Ponieważ dzięki temu zaczyna mieć ono zaufanie do siebie, zyskuje też poczucie bezpieczeństwa. Podczas ćwiczeń ruchowych dziecko może poznać przestrzeń, w której się znajduje. Przestaje być ona dla niego groźna, czuje się w niej bezpieczniej, staje się bardziej aktywne, przejawia większą inicjatywę, staje się twórcze, odważniejsze.

2 Por. M. Bogdanowicz, A. Kasica, Ruch Rozwijający dla wszystkich, Gdańsk 2003. 
W Metodzie Ruchu Rozwijającego wyróżnia się kilka kategorii ruchu, które składają się jednocześnie na etapy terapii: ruch prowadzący do poznania własnego ciała, ruch kształtujący związek człowieka $\mathrm{z}$ otoczeniem, ruch mający na celu wytworzenie relacji z drugim człowiekiem, ruch ukierunkowany na współdziałanie w grupie. MRRWS stała się bardzo popularna ze względu na szeroki zakres oddziaływania. Choć autorka opracowała ją z myślą o dzieciach niepełnosprawnych (głównie intelektualnie), skorzystać $\mathrm{z}$ niej mogą również dzieci o prawidłowym rozwoju, a także osoby z zaburzeniami w sferze emocjonalnej (np. nerwowe, nadpobudliwe, lękliwe), społecznej (np. zamknięte w sobie, nieśmiałe), z zaburzeniami mowy (np. jąkające się), przejawiające trudności o charakterze dyslektycznym.

Metoda Weroniki Sherborne może być stosowana jako forma profilaktyki oraz metoda wsparcia w sytuacjach trudnych. Może wspomagać lub stymulować rozwój, ale i zapobiegać powstawaniu zaburzeń, jeśli zostanie włączona w program, np. przygotowania dziecka, które rozpoczyna edukację przedszkolną lub naukę w szkole, zajęć integrujących grupę przedszkolną lub zespół klasowy, przygotowania rodzin adopcyjnych i zastępczych do przyjęcia dziecka i jego pobytu w rodzinie, przygotowania młodych małżeństw do pełnienia roli rodziców. MRRWS (lub jej elementy) może też być formą relaksacji lub pomocą w osiąganiu odprężenia, zwłaszcza gdy chodzi o ćwiczenia odprężająco-relaksacyjne w trakcie zajęć przedszkolnych lub szkolnych czy zajęcia relaksacyjne dla rodziców. Inną możliwością wykorzystania metody (głównie w pracy $\mathrm{z}$ dorosłymi ${ }^{3}$ ) jest prowadzenie tego typu zajęć $\mathrm{w}$ celu zbudowania $\mathrm{w}$ danej grupie atmosfery wzajemnego zaufania, poczucia bezpieczeństwa, współpracy.

\section{Stosowanie metody Weroniki Sherborne w Polsce}

Metoda Ruchu Rozwijającego jest upowszechniana w Polsce ${ }^{4}$ od przełomu lat siedemdziesiątych i osiemdziesiątych XX wieku. Była ona w naszym kraju kilkakrotnie prezentowana przez Weronikę Sherborne i jej uczniów: Annę Leonard - nieżyjącą już dyrektorkę „szkoły życia” w Londynie oraz George’a Hilla - byłego dyrektora centrum rehabilitacji dla dorosłych osób upośledzonych w Bristolu. Z metodą mieli okazję także zapoznać się polscy specjaliści w czasie pobytu w Wielkiej Brytanii (m.in. Maria Przasnyska, Marta Bogdanowicz). Metoda jest wykorzystywana w Polsce w domach pomocy społecznej, w domach dziecka, w placówkach oświatowych i służby zdrowia dla osób zdrowych i z różnymi zaburzeniami rozwoju: niepełnosprawnych intelektualnie, z autyzmem, z mózgowym porażeniem dziecięcym, z zaburzeniami emocjonalnymi i zaburzeniami zachowania, głuchych i niewidomych. Nierzadko bywa stosowana jako wstęp do innych zajęć terapeutycznych lub ich część ${ }^{5}$ Metoda ta ma również wartość

3 D. Okrzesik, Ruch Rozwijający także dla dorosłych, w: M. Bogdanowicz, A. Kasica, Ruch Rozwijający dla wszystkich, dz. cyt., s. 126-127.

4 Zob. M. Bogdanowicz, A. Kasica, Ruch Rozwijający dla wszystkich, dz. cyt., s. 28-77.

5 Zob. M. Bogdanowicz, B. Kisiel, M. Przasnyska, Metoda Weroniki Sherborne w terapii $i$ wspomaganiu rozwoju dziecka, Warszawa 1992. 
diagnostyczną, ponieważ daje terapeucie wgląd w możliwości i specyficzne potrzeby podopiecznego, umożliwia poznanie go i zrozumienie.

Badania dotyczące skuteczności i efektywności MRRWS zaowocowały m.in. opracowaniem Skali Obserwacji Zachowania Dzieci (SOZ-D), a następnie Skali Obserwacji Zachowania Rodziców (SOZ-R) Marty Bogdanowicz ${ }^{6}$. Rok 1991 przyniósł pomiary Małgorzaty Lisieckiej w przedszkolu specjalnym, w 1995 roku pojawiły się badania Małgorzaty Masalskiej w przedszkolu integracyjnym. W latach 1995-1996 badania Janiny Tłustochowicz w ,szkole życia” poszerzyły zakres obserwacji naukowych. W 1998 roku w domu opieki społecznej Agata Winiarz gromadziła kolejne dane, zaś w roku 2000 ukazały się wyniki badań Dominiki Jarmołowicz ze środowiskowego domu samopomocy. W kolejnym, 2001 roku Katarzyna Nowicka-Pikuła opracowała efekty badań w grupie przedszkolnej „szkoły życia”. Następnie Alina Czapiga przeprowadziła badania nad zastosowaniem MWS w zakładzie leczniczo-wychowawczym dla osób z niepełnosprawnością intelektualną w stopniu znacznym i głębokim, zaś Marta Bogdanowicz i Alicja Kasica mierzyły efektywność MRRWS w placówkach szkolno-wychowawczych dla dzieci z głębszym upośledzeniem umysłowym (2001-2003).

\section{EFEKTYWNOŚĆ MRR W TERAPII DZIECI Z NIEPEENOSPRAWNOŚCIĄ INTELEKTUALNĄ}

W latach 2001-2003 w dziewięciu polskich placówkach szkolno-wychowawczych dla dzieci z niepełnosprawnością intelektualną badano skuteczność działania $\mathrm{MRR}^{7}$. Badanie przeprowadziły Marta Bogdanowicz i Alicja Kasica. Wzięło w nim udział 71 dzieci niepełnosprawnych intelektualnie w stopniu umiarkowanym w wieku od 5-15 lat, które uczestniczyły w zajęciach raz w tygodniu w wymiarze 45 do 60 minut $^{8}$. Badanie pozwoliło stwierdzić: poprawę ogólnego funkcjonowania dzieci uczestniczących w terapii MRR, pozytywny wpływ uczestnictwa w zajęciach na rozwój emocjonalny, pozytywny wpływ na rozwój społeczny dzieci w zakresie umiejętności związanych z nawiązywaniem relacji z drugą osobą oraz umiejętności współpracy z grupą, pozytywny wpływ na rozwój poznawczy w zakresie świadomości własnego ciała, pozytywny wpływ na rozwój ruchowy. Dzięki badaniu udowodniono również pozytywny wpływ terapii MRR na tempo i rytm rozwoju dzieci niepełnosprawnych intelektualnie ${ }^{9}$.

Dodać trzeba, że MRRWS uaktywnia funkcjonowanie człowieka w czterech obszarach: poznawczym, emocjonalnym, społecznym, fizycznym (motoryka/ruch) ${ }^{10}$. Polskie procedury oceniania MRRWS obejmują: mobilność, świadomość części ciała,

6 Zob. M. Bogdanowicz, A. Kasica, Ruch Rozwijający dla wszystkich, Gdańsk 2016, s. 141-166.

7 M. Bogdanowicz, A. Kasica, Ruch Rozwijający dla wszystkich, dz. cyt., s. 61-77.

8 Sesje mogą być krótsze, gdy wymaga tego sytuacja, np. wiek lub stan zdrowia uczestników.

9 W przypadku dzieci z głębszą niepełnosprawnością intelektualną zaleca się dłuższy czas trwania terapii MRR w celu zwiększenia korzyści dla uczestników.

10 M. Bogdanowicz, A. Kasica, Ruch Rozwijający dla wszystkich, dz. cyt., s. 30-36. 
świadomość środka ciała, przestrzeń ogólną, kontakt z partnerem podczas ćwiczeń, w tym relację „z”, relację „przeciwko”, relację „razem”, współpracę z grupą, cechy ruchu, kreatywność ${ }^{11}$.

\section{KRÓtKA CHARAKTERYSTYKA MRRWS}

Laban i Sherborne wskazują na kilka kategorii ruchu, wyodrębniając następujące:

- ruch prowadzący do poznania własnego ciała wraz z wypracowaniem umiejętności kontroli (wyróżnianie części ciała i kontrola nad nimi; utrzymanie równowagi; wiedza i kontrola nad ruchami prowadzą do uformowania tożsamości oraz „ja”; przykłady ćwiczeń: leżenie na plecach, ślizganie się w kółko na brzuchu, bieganie, chodzenie na sztywnych nogach, dotykanie łokciami kolan, wytrzeszczanie i mrużenie oczu, zabawne miny);

- ruch kształtujący związek jednostki z otoczeniem fizycznym (rozwijanie orientacji przestrzennej, otwartości na świat; ćwiczenia pomagające zdobyć pewność siebie i poczucie bezpieczeństwa w otoczeniu; np. ćwiczenia w parach, ćwiczenia w grupach);

- ruch wiodący do wytworzenia się związku z drugim człowiekiem (wypracowanie zaufania, zrozumienie potrzeb innych osób, budowanie relacji) oraz ruch prowadzący do współdziałania w grupie (zaangażowanie uczestników, współdziałanie); ćwiczenia ułatwiające nawiązywanie kontaktu i kooperację z partnerem oraz grupą (ćwiczenia „z" w parach, ćwiczenia „przeciwko” w parach, ćwiczenia „razem” w parach, ćwiczenia „razem” w grupie);

- ruch kreatywny (wyzwala spontaniczność, twórczość, swobodę), obejmuje przede wszystkim ćwiczenia twórcze (np. taniec, własne propozycje uczestników, które pomagają w uwolnieniu się od wewnętrznych napięć, niepokojów, stresów) ${ }^{12}$.

\section{Przeznaczenie i zastosowanie Metody Ruchu Rozwijającego}

Metodę Weroniki Sherborne można zaliczyć do niewerbalnych treningów interpersonalnych. Zajęcia w grupie są szansą na zdobywanie i wzbogacanie doświadczeń spolecznych. Mogą wspierać dzieci w nauce bycia z innymi, czerpania satysfakcji z różnych form kontaktów społecznych, dorosłym zaś pomagają rozumieć własne dziecko i siebie.

Jako metoda terapii MRRWS znajduje zastosowanie w pracy z dziećmi z zaburzeniami rozwoju psychoruchowego, w przypadkach niepełnosprawności intelektualnej.

11 M. Bogdanowicz, A. Kasica, Ruch Rozwijający dla wszystkich, dz. cyt., s. 28-29.

12 Kreatywność rozumiana jest jako manifestacja wewnętrznych stanów świadomości i uczuć człowieka. Narastanie i gromadzenie napięć może prowadzić do poważnych zaburzeń psychicznych. 
Również dla dzieci z tzw. normą intelektualną, przejawiających zaburzenia w zakresie sfery emocjonalnej i społecznej, zajęcia Ruchu Rozwijającego są bardzo wskazane. Metoda ta bywa wykorzystywana jako wstępny etap do innych zajęć terapeutycznych, np. dla dzieci mających trudności w czytaniu i pisaniu, czy jako część programu terapii psychologiczno-logopedycznej dzieci jąkających się lub w psychoterapii dzieci nerwicowych.

Ruch Rozwijający wyzwala naturalność i zaangażowanie. Jest okazją do uaktywniania wspomnień z dzieciństwa. Motywuje do rozładowywania napięć, uwalniania energii, wypracowywania poczucia bezpieczeństwa i zaufania, sprzyja budowaniu poczucia własnej wartości. Stanowi formę kontaktu z innymi bez uruchamiania sfery seksualnej. Daje możliwość odczuwania przyjemnych doznań płynących z własnego ciała. Uczy partnerstwa, działania w zespole oraz odczuwania przyjemności z dawania innym radości. Jest sposobem działania dającym szansę na wspieranie prawidłowego rozwoju dziecka oraz wpływającym na poprawę funkcjonowania dziecka i rodziny ${ }^{13}$. Jest zatem metodą uniwersalną, o wielu możliwościach stosowania; skuteczna jako metoda terapeutyczna, daje się też z powodzeniem wykorzystać w profilaktyce, może być przydatna w budowaniu i kształtowaniu doświadczeń psychologicznych i społecznych osób zainteresowanych własnym rozwojem. Właśnie do tego zachęca również Marta Bogdanowicz.

\section{LITERATURA}

Bogdanowicz M., Metoda Weroniki Sherborne w Polsce, „Schoolasticus” (1992) nr 2, s. 39-41.

Bogdanowicz M., Skale obserwacji zachowania dzieci i rodziców, Gdańsk 2006.

Bogdanowicz M., Kasica A., Ruch Rozwijający dla wszystkich, Gdańsk 2016.

Bogdanowicz M., Kisiel, B., Przasnyska M., Metoda Weroniki Sherborne w terapii i wspomaganiu rozwoju dziecka, wyd. 2, Warszawa 1994.

Bogdanowicz M., Okrzesik D., Opis i planowanie zajęć wedlug Metody Ruchu Rozwijającego Weroniki Sherborne, wyd. 7, Gdańsk 2014.

Przasnyska M., Nauczanie kultury fizycznej w szkole życia wedlug ,programu ruchu” Weroniki Sherborne, „Szkoła Specjalna” (1989) nr 2, s. 130-136.

Sherborne W., Ruch Rozwijajacy dla dzieci, przeł. M. Bogdanowicz, Warszawa 1999.

13 M. Bogdanowicz, A. Puchalska, Ankiety dla rodziców - na poczatku i na zakończenie cyklu zajęć, w: M. Bogdanowicz, A. Kasica, Ruch Rozwijajacy dla wszystkich, dz. cyt., s. 167-175. 